\title{
Intraperitoneal analgesia for postoperative pain relief after laparoscopic gynecological surgeries
}

\author{
Basant Kumar Pati* \\ Department of Obstetrics and Gynecology, Institute of Medical Sciences and SUM Hospital, Bhubaneswar, Odisha, \\ India
}

Received: 09 September 2017

Accepted: 05 October 2017

\section{*Correspondence:}

Dr. Basant Kumar Pati,

E-mail: basantapati@soauniversity.ac.in

Copyright: (C) the author(s), publisher and licensee Medip Academy. This is an open-access article distributed under the terms of the Creative Commons Attribution Non-Commercial License, which permits unrestricted non-commercial use, distribution, and reproduction in any medium, provided the original work is properly cited.

\section{ABSTRACT}

Background: Though laparoscopic gynaecological surgeries are less invasive and produces less post-operative pain, post-laparoscopy pain is still a concern. Intraperitoneal (IP) instillation of local anaesthetics has been shown to minimize the postoperative pain after laparoscopic surgeries. This study was conducted to compare the efficacy of intraperitoneal instillation of dexmedetomidine with bupivacaine and bupivacaine alone in reducing postoperative pain.

Methods: 60 patients, enrolled for gynaecological laparoscopic surgeries were divided randomly into two groups of 30 each. Group B: Bupivacaine $(30 \mathrm{ml}, 0.25 \%)$ with $2 \mathrm{ml}$ normal saline was instilled prior to removal of trocars, and Group BD: Bupivacaine $(30 \mathrm{ml}, 0.25 \%)$ with dexmedetomidine $(1 \mathrm{mcg} / \mathrm{kg}$, diluted to $2 \mathrm{ml})$ was instilled prior to removal of trocars. In postoperative period, Visual Analogue Score (VAS) was recorded up to 24 hours. Postoperative analgesic requirements, and side effects were recorded.

Results: The Visual Analogue Score (VAS) during the first postoperative 24 hours was significantly lower in group $\mathrm{BD}$ compared to group B. Time to first analgesia required was delayed and total analgesic consumption was lower in group BD compared to group B which was statistically significant.

Conclusions: Intraperitoneal instillation of dexmedetomidine with bupivacaine is an effective and safe method for reducing pain after laparoscopic gynaecological surgeries.

Keywords: Dexmedetomidine, Gynaecological, Intra-peritoneal instillation, Laparoscopic

\section{INTRODUCTION}

Laparoscopic surgeries have advantages over open procedures. They are less haemorrhage, better cosmetic results, less postoperative pain; and short recovery time, short hospital stay and less expenditure. ${ }^{1}$ Laparoscopic gynaecological surgeries have been increased recently due to the above advantages. Postoperative pain management remains a major challenge after laparoscopic surgeries. ${ }^{2}$ Effective pain management provides early ambulation, which significantly reduces the risk of deep vein thrombosis and pulmonary embolism. ${ }^{3}$ This increases patient's ability to take deep breaths to decrease the risk of pulmonary complications like atelectasis and pneumonia. Pain after laparoscopic surgery has two components like visceral and somatic. Visceral component is due to surgical handling, tissue injury, and the stretching of nerve endings. ${ }^{4}$ Pneumoperitoneum produce stretching of the peritoneum and the diaphragmatic muscle fibres, which irritates phrenic nerve endings. As this nerve shares a common route with nerves that innervate the shoulder, it may produce shoulder pain. The somatic component of pain is due to the holes made in the abdominal wall for the entry of trocar. ${ }^{5}$ Various methods are available for management of postoperative pain but still preventing and relieving the 
pain remains a challenge. It has been reported that the postoperative pain is inadequately treated in approximately one half of all surgical procedures. ${ }^{6}$ Therefore, a multimodal approach, using local anaesthetics with adjuvants may help in improving the quality of analgesia, without producing any side effects. ${ }^{7}$ The aim of this study was to assess the effect of intraperitoneal bupivacaine with dexmedetomidine in reducing postoperative pain after laparoscopic surgeries. The primary outcome was to assess the postoperative pain scores. Secondary outcomes were assessment of postoperative analgesic requirements and side effects.

\section{METHODS}

This prospective, double-blind, randomized and controlled study was conducted in 60 patients of aged 45 to 65 years posted for laparoscopic gynecological surgeries. All patients were divided into two groups and an informed written consent was obtained from all patient. Patients were posted for laparoscopic hysterectomy with either salpingectomy or salpingooophorectomy.

Pregnancy, genital malignancy, deep pelvic endometriosis, or inflammatory bowel disease, current opioid use was excluded from study.

History of all patients was obtained and general, abdominal, and local pelvic examination was done. Preanesthetic check-up and routine investigations, such as complete blood count test, random blood sugar level, liver and renal function tests and coagulation profile were done. Patients were explained regarding use of the VAS. ${ }^{8}$ All patients were randomly assigned to one of the two groups: Group-B: 30 patients received bupivacaine, and Group-BD: 30 patients received bupivacaine with dexmedetomidine. On arrival in the operating room, standard intraoperative anesthetic, analgesic, and antiemetic were administered in all cases. Laparoscopic surgery was started after establishment of carbon dioxide pneumoperitoneum. Trendelenburg's position was performed at 30 degrees and 3 accessory trocars were then inserted (two lateral pelvic and one suprapubic). Intraabdominal pressure was maintained below $15 \mathrm{~mm}$ of $\mathrm{Hg}$. At the end of surgery, prior to removal of trocars, a $32 \mathrm{ml}$ of study drug was instilled intraperitoneally. In Group B, Bupivacaine (30 ml, 0.25\%) with $2 \mathrm{ml}$ normal saline and in Group BD, Bupivacaine $(30 \mathrm{ml}, 0.25 \%)$ with dexmedetomidine (1 $\mathrm{mcg} / \mathrm{kg}$, diluted to $2 \mathrm{ml}$ ) was instilled prior to removal of trocars. All surgeries were performed by surgeon, who was not informed about the content of the instilled study drug. After operation, the postoperative pain was assessed using the Visual Analogue Score (VAS) and recorded at 0.5, 1, 4, 8, 12, 16 and 24 hours postoperatively. Patients who had VAS $>4$, were administered a IV paracetamol $(1 \mathrm{~g})$ injection as rescue analgesia. Time to first postoperative analgesic requirement, total analgesic requirement and occurrence of side effects like nausea and vomiting in the first 24 hours postoperatively were recorded. All data was expressed as mean, standard deviation, number, and percent. Statistical analysis was performed using Statistical Package for Social Sciences (SPSS/version 20) software. For categorized data Chi square test was used while for numerical data t-test was used to compare two groups. $\mathrm{P}<0.05$ was considered as significant.

\section{RESULTS}

There were no significant differences between the two studied groups with respect of basic characteristics like age, body mass index and duration of surgery (Table 1).

Table 1: Demographic data.

\begin{tabular}{|llll|}
\hline Parameter & Group B & Group BD & P value \\
\hline Age (year) & $49.6 \pm 10.4$ & $48.9 \pm 11.5$ & 0.43 \\
\hline Weight $(\mathrm{kg})$ & $60.7 \pm 10.5$ & $62.4 \pm 8.7$ & 0.36 \\
\hline Height $(\mathrm{cm})$ & $161.4 \pm 7.9$ & $163.4 \pm 8.1$ & 0.38 \\
\hline $\begin{array}{l}\text { Duration of } \\
\text { surgery (minutes) }\end{array}$ & $70.4 \pm 10.8$ & $72.6 \pm 10.2$ & 0.32 \\
\hline
\end{tabular}

Regarding postoperative pain assessment, VAS at different time interval after laparoscopy was less in group BD compared to group B which was statistically significant (Table 2).

Table 2: VAS (Visual analogue score).

\begin{tabular}{|llll|}
\hline Time (hours) & Group B & Group BD & P value \\
\hline At 0.5 & $4.1 \pm 1.5$ & $3.6 \pm 0.4$ & $<0.05$ \\
\hline At 1 & $5.6 \pm 1.1$ & $3.9 \pm 0.1$ & $<0.05$ \\
\hline At 4 & $5.9 \pm 1.2$ & $3.1 \pm 0.7$ & $<0.05$ \\
\hline At 8 & $4.8 \pm 1.3$ & $3.4 \pm 0.6$ & $<0.05$ \\
\hline At 12 & $4.3 \pm 1.5$ & $2.9 \pm 0.9$ & $<0.05$ \\
\hline At 16 & $5.5 \pm 1.3$ & $3.1 \pm 1.0$ & $<0.05$ \\
\hline At 24 hours & $3.9 \pm 1.2$ & $3.0 \pm 0.9$ & $<0.05$ \\
\hline
\end{tabular}

Table 3: Comparison between the two studied groups regarding postoperative analgesia.

\begin{tabular}{|llll|}
\hline $\begin{array}{l}\text { Postoperative } \\
\text { analgesia }\end{array}$ & Group B & Group BD & $\begin{array}{l}\text { P } \\
\text { value }\end{array}$ \\
\hline $\begin{array}{l}\text { Time for } 1^{\text {st }} \\
\text { analgesia request } \\
\text { (in minutes) }\end{array}$ & $165.5 \pm 30.8$ & $310.4 \pm 32.5$ & $<0.05$ \\
\hline $\begin{array}{l}\text { Amount of } \\
\text { Paracetamol } \\
\text { needed (gm) }\end{array}$ & $3.6 \pm 0.4$ & $1.2 \pm 0.8$ & $<0.05$ \\
\hline
\end{tabular}

Postoperative analgesia was assessed by observing the time required for $1^{\text {st }}$ analgesic dose and amount of analgesia needed. There was a significant increase in the time required for 1st rescue analgesia in group $\mathrm{BD}$ more than group B $(165.5 \pm 30.8$ minutes versus $310.4 \pm 32.5$ minutes). Amount of paracetamol needed was significantly less in group BD (1.2 $\pm 0.8 \mathrm{gm})$ compared to group B (3.6 $\pm 0.4 \mathrm{gm})$ (Table 3$)$. Table 4 showed that 
patients in group BD had significantly less side effects like nausea, vomiting and shoulder pain compared to group B (Table 4).

Table 4: Side effects.

\begin{tabular}{|lll|}
\hline Variable & Group B $(n)$ & Group BD $(n)$ \\
\hline Nausea & 8 & 2 \\
\hline Vomiting & 6 & 3 \\
\hline Shoulder pain & 6 & 2 \\
\hline
\end{tabular}

\section{DISCUSSION}

Many methods have been investigated for an optimum pain relief in the postoperative period out of which, intraperitoneal instillation of local anesthetic agents offer theoretical and practical advantages over other methods. ${ }^{9}$ Intraperitoneal instillation of local anesthetics with adjuvants was started in early 1990s during laparoscopic surgery. ${ }^{10}$ In laparoscopic surgeries because of gas insufflations and raised intraperitoneal pressure, there is peritoneal inflammation and neuronal rupture with a linear relationship between abdominal compliance and resultant severity of post-operative pain. Hence, we choose intraperitoneal route because it blocks the visceral afferent signals and modifies visceral nociception. ${ }^{11,12}$ The local anesthetic agents provide antinociception by affecting nerve membrane associated proteins and by inhibiting the release and action of prostaglandins which stimulates the nociceptors and cause inflammation. Intraperitoneal instillation of $0.25 \%$ bupivacaine provides effective analgesia.

To prolong the duration of analgesia, we have added dexmedetomidine to bupivacaine. In the present study, intraperitoneal instillation of local anesthetics was done prior to removal of trocars. There was significant reduction in pain scores during the first 24 hours following surgery in Bupivacaine-dexmedetomidine group. The incidence of postoperative nausea and vomiting and shoulder pain was less with Bupivacainedexmedetomidine group.

Narchi et al in their study found that intraperitoneal instillation of local anesthetics are more effective in reducing pain up to 48 hours postoperatively in patients undergoing diagnostic laparoscopy. ${ }^{13}$ Golubovic et al assessed the analgesic effects of intraperitoneal instillation of bupivacaine and tramadol in patients undergoing laparoscopic cholecystectomy and concluded that intraperitoneal instillation of bupivacaine or tramadol or combination of both are effective method for management of pain after laparoscopic cholecystectomy. ${ }^{14}$ Bisgaard et al had reported that the visceral pain experienced after laparoscopic cholecystectomy can be theoretically blocked by IP analgesic instillation. ${ }^{15}$ The results of the present clinical trial seem to be in accordance with the findings of these studies. Present results correlate with study done by Ahmed et al which has shown that intraperitoneal instillation of mepiridine or dexmedetomidine in combination with bupivacaine $0.25 \%$ significantly decreases the post-operative analgesic requirements and decreased incidence of shoulder pain in patients undergoing laparoscopic gynaecological surgeries. ${ }^{16}$ Memis et al studied the effects of tramadol or clonidine added to intraperitoneal bupivacaine, on post-operative pain in total abdominal hysterectomy and found that combination of tramadol or clonidine with intraperitoneal bupivacaine was more effective than bupivacaine alone. ${ }^{17}$ In gynecologic laparoscopy, one previous study carried out by Goldstein et al reported that the intraperitoneal instillation of $20 \mathrm{ml}$ of either $0.5 \%$ bupivacaine or $0.75 \%$ ropivacaine prevented postoperative pain and decreased the need for postoperative analgesia, when compared with placebo in patients undergoing laparoscopic gynaecologic surgery. ${ }^{18}$ Arden D et al have compared instillation of $100 \mathrm{mg}$ bupivacaine in $100 \mathrm{ml}$ normal saline with instillation of $100 \mathrm{ml}$ normal saline alone and concluded that bupivacaine was effective in reducing postoperative pain. ${ }^{19}$ Ranjita et al in his study concluded that better postoperative analgesia can be provided with intraperitoneal, ropivacaine with dexamedetomidine after laparoscopic hysterectomy compared to ropivacaine alone. ${ }^{20}$ These results agree with the current study. Early mobilization was possible in the group which received local intraperitoneal instillation analgesia with dexmedetomidine.

\section{CONCLUSION}

We conclude that intraperitoneal instillation of bupivacaine in combination with dexmedetomidne in laparoscopic gynaecological surgeries significantly reduces the postoperative pain and significantly reduces the analgesic requirement in the postoperative period as compared to control group without any side effects.

\section{Funding: No funding sources}

Conflict of interest: None declared

Ethical approval: The study was approved by the Institutional Ethics Committee

\section{REFERENCES}

1. Kim TH, Kang HK, Park JS, Chang IT, Park SG. Intraperitoneal ropivacaine instillation for postoperative pain relief after laparoscopic cholecystectomy. J Korean Surg Soc. 2010;79:130-6.

2. Wu JM, Wechter ME, Geller EJ, Nguyen TV, Visco AG. Hysterectomy rates in the United States. Obstet Gynecol. 2003;2007:1091-5.

3. Kai-Yun Wu, Lertvikool S, Huang K, Su H, Yen C, Lee C. Laparoscopic hysterectomies for large uteri. Taiwanese J Obstet Gynecol. 2011;50:411-4.

4. El-Sherbiny W, Saber W, Askalany AN, El-Daly A, Sleem AA. Effect of intra-abdominal instillation of lidocaine during minor laparoscopic procedures. Int $\mathbf{J}$ Gynecol Obstet. 2009;106:213-5. 
5. Pasqualucci A, de Angelis V, Contardo R, Colò F, Terrosu G, Donini A et al. Preemptive analgesia: intraperitoneal local anesthetic in laparoscopic cholecystectomy. A randomized, double-blind, placebo-controlled study. Anesthesiol. 2000;85:1120.

6. White PF. The role of non-opioid analgesic techniques in the management of postoperative pain. Anesth Analg. 2002;94:577-85.

7. Cruz JJ, Diebolder H, Dogan A, Mothes A, Rengsberger M, Hartmann M, et al. Combination of pre-emptive port-site and intraoperative intraperitoneal ropivacaine for reduction of postoperative pain: a prospective cohort study. Eur J Obstet Gynecol Reprod Biol. 2014;179:11-6.

8. Huang S, Mi S, He Y, Li Y, Wang S. Analgesic efficacy of trocar sites local anesthetic infiltration with and without transversus abdominis plane block after laparoscopic hysterectomy: a randomized trial. Int J Clin Exp Med. 2016;9(3):6518-24.

9. Marks JL, Ata B, Tulandi T. Systematic review and metaanalysis of intraperitoneal instillation of local anesthetics for reduction of pain after gynecologic laparoscopy. J Minim Invasive Gynecol. 2012;19:545-53.

10. Andrews V, Wright JT, Zakaria F, Banerjee S, Ballard K. Continuous infusion of local anesthetic following laparoscopic hysterectomy: a randomized controlled trial. Br J Obstet Gynecol. 2014;121:75561.

11. Rivard C, Vogel RI, Teoh D. Effect of intraperitoneal bupivacaine on postoperative pain in the gynecologic oncology patient. J Minim Invasive Gynecol. 2015;22(7):1260-5.

12. Saccardi C, Gizzo S, Vitagliano A, Noventa M, Micaglio M, Parotto M, et al. Peri-incisional and intraperitoneal ropivacaine administration: a new effective tool in pain control after laparoscopic surgery in gynecology: a randomized controlled clinical trial. Surg Endosc. 2016;30(12):5310-8.

13. Narchi $P$, Benhamou D, Fernandez H. Intraperitoneal local anesthetic for shoulder pain after day-case laparoscopy. Lancet. 1991;338:1569-70.
14. Golubovic S, Golubovic V, Tokmadzic VS. Intraperitoneal analgesia for laproscopic cholecystectomy. Periodicum Biologorum. 2009;3:263-6.

15. Goldstein A, Grimault P, Henique A, Keller M, Fortin A, Darai E. Preventing postoperative pain by local anesthetic instillation after laparoscopic gynecologic surgery: A placebo-controlled comparison of bupivacaine and ropivacaine. Anesth Analg. 2000;91:403-7.

16. Bisgaard T, Klarskov B, Kristiansen VB, Callesen T, Schulze S, Kehlet $\mathrm{H}$, et al. Multi-regional local anesthetic infiltration during laparoscopic cholecystectomy in patients receiving prophylactic multi modal analgesia: a randomized, double blinded, placebo-controlled study. Anesth Analg. 2009;89:1017-24.

17. Ahmed B, Elmawgoud AA, Dosa R. Antinociceptive effect of ( $\dot{\alpha}-2$ adrenoceptor agonist) dexmedetomidine versus meperidine, topically, after laproscopic gynecologic surgery. J Med Sci. 2008;8:400-4.

18. Memis D, Turan A, Karamanlioglu B, Tükenmez B, Pamukçu Z. The effect of tramadol or clonidine added to intraperitoneal bupivacaine on postoperative pain in total abdominal hysterectomy. $\mathrm{J}$ Opioid Manag. 2005;1:77-82.

19. Arden D, Seifert E, Donnellan N, Guido R, Lee T, Mansuria S. Intraperitoneal instillation of bupivacaine for reduction of postoperative pain after laparoscopic hysterectomy: a double-blind randomized controlled trial. J Minim Invasive Gynecol. 2013;20:620-6.

20. Ranjita A, Daisy K, Megha K. Postoperative analgesia with intraperitoneal, ropivacaine with and without dexamedetomidine after total laparoscopic hysterectomy: Asian J Pharmaceu Clin Res. 2016;9:1-4.

Cite this article as: Pati BK. Intraperitoneal analgesia for postoperative pain relief after laparoscopic gynaecological surgeries. Int J Reprod Contracept Obstet Gynecol 2017;6:5099-5102. 